Check for updates

Cite this: RSC Adv., 2019, 9, 3294

\title{
Ethanol dehydrogenative reactions catalyzed by copper supported on porous Al-Mg mixed oxides $\uparrow$
}

\author{
Davi D. Petrolini, (D) a Wellington H. Cassinelli, ${ }^{b}$ Cristiane A. Pereira, ${ }^{c}$ \\ Ernesto A. Urquieta-González, ${ }^{c}$ Celso V. Santilli ${ }^{a}$ and Leandro Martins (D)*a
}

\begin{abstract}
Mixed aluminum and magnesium oxides (AlMgO) prepared by means of an emulsion-mediated sol-gel method was impregnated with copper nitrate solution and used in the ethanol dehydrogenative reactions to produce acetaldehyde and ethyl acetate. The emulsified system allowed to obtain a macromesoporous support that resulted in an outstanding dispersion of copper. The porous catalyst was about 3 times more active than the non-porous counterpart, due to the formation on the support's surface of $\mathrm{Cu}^{0}$ together with the more active $\mathrm{Cu}^{+}$species. In fact, the simultaneous presence of $\mathrm{Cu}^{+}$and $\mathrm{Cu}^{0}$ were advantageous for the catalytic performance, as the turnover frequencies, were 122 and $166 \mathrm{~h}^{-1}$ for the non-porous reference catalyst and for the porous one, respectively. Both catalysts deactivated due to copper particles sintering, however the porous one deactivated less, as a consequence of the better dispersion of the $\mathrm{Cu}$ species on the macro and mesoporous support. Acetaldehyde was the main product, however by increasing the contact time by 6.6 times, the conversion of ethanol on the nonporous catalyst reached about $90 \%$ with a selectivity to ethyl acetate of $20 \%$ by means of the coupling reaction of ethanol and acetaldehyde. The selectivity to ethyl acetate was favoured on an increased support/copper interface that is given by larger copper particles.
\end{abstract}

Received 7th December 2018

Accepted 10th January 2019

DOI: $10.1039 / c 8 r a 10076 d$

rsc.li/rsc-advances
Ethanol dehydrogenation stands out by the importance of the products hydrogen and acetaldehyde, which can be used as an intermediates in the manufacture of acetic acid, acetic anhydride, ethyl acetate, butyraldehyde, crotonaldehyde and $n$ butanol. ${ }^{3,5-10}$ Though it has a lower hydrogen yield compared to the ethanol reforming reactions, ethanol dehydrogenation is carried out at lower temperatures. Even whether ethanol reforming is operated at mild temperatures, it still generates carbon monoxide, which causes loss of efficiency and early fuel cell poisoning. ${ }^{8}$ Moreover, the coupling reaction to further give ethyl acetate is a very attractive sustainable strategy, ${ }^{\mathbf{9 , 1 0}}$ because it enables the production of esters directly from alcohols. Compared to the traditional esterification of ethanol with carboxylic acids, the coupling is advantageous due to the reduction of wastes and enhancement of process profit.

Some aspects are critical to guarantee high ethyl acetate yield during the catalytic ethanol coupling reaction, such as the acidbase property of the catalyst, which if not properly tuned, it can lead to unwanted by-products. The porosity of the support is another important property because it influences the particle size and the oxidation state of copper species, which are the active ones for the mentioned reactions. ${ }^{11}$ A detailed kinetic and mechanistic study on $\mathrm{Cu} / \mathrm{Cr}_{2} \mathrm{O}_{3}$ showed the central role of copper in the adsorption and dehydrogenation of ethanol, which is due to its ability to preserve intact the $\mathrm{C}-\mathrm{C}$ bonds and facilitate the hydrogen transfer reactions. ${ }^{12}$ In addition, it was emphasized the negative effect of the Brønsted acid sites of
${ }^{a}$ Instituto de Quimica, UNESP - Universidade Estadual Paulista, R. Prof. Francisco Degni 55, 14800-900 Araraquara, SP, Brazil.E-mail: leandro.martins@unesp.br

${ }^{b}$ Instituto Federal de São Paulo - Campus Avaré, Av. Prof. Celso Ferreira da Silva, 1333, Jardim Europa, 18707-150, Avaré, SP, Brazil

${ }^{c}$ Centro de Pesquisas em Materiais Avançados e Energia - Universidade Federal de São Carlos, Rodovia Washington Luis, km 235, CEP 13565-905, São Carlos, SP, Brazil

$\dagger$ Electronic supplementary information (ESI) available. See DOI: 10.1039/c8ra10076d 
$\mathrm{Cr}_{2} \mathrm{O}_{3}$ that prevent desorption of acetaldehyde and make this a rate determinant step, which results in limited activity, without considering the unwanted capacity of the Brønsted acid sites to dehydrate ethanol. ${ }^{12}$ Therefore, the appropriate balance of acid-base sites of the support is crucial for the dehydrogenative coupling of alcohols.

The use of aluminum and magnesium mixed oxides derived from hydrotalcites as support for impregnation of copper species and forward application in the dehydrogenation of alcohols is motivating. After heat treatment, these mixed oxides have various unique properties as providing an ideal balance of acid and base sites ${ }^{13-17}$ and unique textural properties, which have impact on metals dispersion and therefore on ethanol conversion to acetaldehyde and ethyl acetate. ${ }^{3,5}$

In a previous study, ${ }^{18-20}$ an emulsion-mediated method was used to produce $\mathrm{Al}-\mathrm{Mg}$ mixed oxides from hierarchically ordered hydrotalcite precursors that gave a high specific surface area. It is expected that the textural properties of these materials may reduce metal agglomeration and increase the interparticle space, and then to have an incremental effect on the catalyst performance. In fact, in situ studies have shown that the catalytic reaction rates are significantly optimized by changing the metal particle size. Moreover, the particle size in copper based catalysts affected the surface ratio of $\mathrm{Cu}^{0}$ to $\mathrm{Cu}^{+}$and consequently the activity in reactions involving oxygenated intermediates. ${ }^{21-26}$ It is known that $\mathrm{Cu}^{0}$ supported catalysts are the most active for ethanol dehydrogenation, but further studies have shown that partially oxidized $\mathrm{Cu}^{+}$directly influence the activity towards ethyl acetate. .,5,6,21,27 $^{-1}$

Herein, we examined how the textural properties and acidbase properties of highly porous aluminum and magnesium mixed oxides prepared from an emulsified synthesis system influence the dispersion of copper species and their oxidation state and, consequently their catalytic performance on the dehydrogenative coupling of ethanol to produce acetaldehyde and ethyl acetate with an enhanced selectivity.

\section{Experimental}

\subsection{Synthesis of the supports and catalysts}

The porous and the reference non-porous aluminummagnesium mixed oxides, with molar fraction of $\mathrm{Al} / \mathrm{Mg}$ of 0.5 , were obtained by sol-gel synthesis, according to a previous method..$^{18,19}$ The synthesis of the porous mixed oxides involved

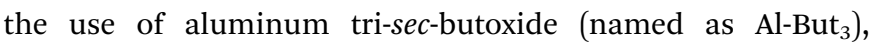
magnesium nitrate, $n$-dodecane as emulsification agent, a nonionic triblock copolymer as emulsion stabilizer (Pluronic P123) and ethanol as solvent. The molar composition was: 0.01 Pluronic : $1 \mathrm{Al}^{-B_{4}}{ }_{3}: 1 \mathrm{Mg}\left(\mathrm{NO}_{3}\right)_{2}: 15$ ethanol. The preparation of the sol involved the dispersion of Pluronic P123 in ethanol at room temperature, followed by addition of $\mathrm{Al}^{-\mathrm{But}_{3}}$ and magnesium nitrate. Subsequently, emulsification was achieved by adding $60 \mathrm{wt} \%$ of $n$-dodecane, under mechanical stirring. The addition of a solution of ammonium hydroxide drop by drop under stirring led to the sol-gel transition. The assynthesized samples were calcined at $500{ }^{\circ} \mathrm{C}$ for $2 \mathrm{~h}$ under air in a conventional muffle oven. For sake of comparison, a reference support was obtained without the use of organic pore structure directing agents (PSDAs), Pluronic 123 and $n$ dodecane. The samples obtained without and using the PSDAs agents were named $\mathrm{AlMgO}$ and AlMgO-P, respectively, in which $\mathrm{P}$ stands for porous. The copper catalysts, with a nominal content of $10 \mathrm{wt} \%$ of copper, were obtained by incipient wetness impregnation of the calcined mixed oxides using an aqueous solution of copper nitrate. After impregnation, the samples were calcined at $500{ }^{\circ} \mathrm{C}$ for $3 \mathrm{~h}$.

\subsection{Characterization of the supports and catalysts}

The porosity and macro and mesopore size distributions of the calcined mixed AlMgO oxides and copper catalysts were assessed by mercury intrusion porosimetry in an AutoPore III instrument from Micromeritics. The samples were degassed at a pressure below $50 \mu \mathrm{Pa}$ before starting the measurements. The Washburn equation ${ }^{28}$ was used to calculate the pore size by using mercury surface tension of $0.489 \mathrm{~N} \mathrm{~m}^{-1}$ and contact angle of $135^{\circ}$.

The porosity of the samples was further characterized by nitrogen adsorption-desorption isotherms at $-196{ }^{\circ} \mathrm{C}$ on an ASAP 2010 instrument from Micromeritics with relative pressure ranging between 0.001 and 0.998 . Prior to the analysis, the samples were vacuum-degassed at $200{ }^{\circ} \mathrm{C}$ for $12 \mathrm{~h}$ under a pressure below to $10 \mu \mathrm{Pa}$. Pore volumes, mesopore size distributions (BJH method) and BET surface area for $P / P_{0}$ up to 0.3 were determined from the isotherms. ${ }^{29}$

The microstructure of mixed oxides was analyzed by scanning electron microscopy (SEM), using a Philips XL 30 equipment. The samples were deposited on an aluminum sample holder and sputtered with gold.

$\mathrm{X}$-ray diffraction profiles of the copper catalysts were recorded using a Siemens D5000 diffractometer equipped with a $\mathrm{CuK} \alpha$ radiation (selected by a curved graphite monochromator). The protocol of the scanning steps was $2 \theta$ range from $3^{\circ}$ to $80^{\circ}$, with step size of $0.02^{\circ}$, and counting time of $1 \mathrm{~s}$.

Temperature programmed desorption of ammonia $\left(\mathrm{NH}_{3}-\right.$ TPD) and of carbon dioxide ( $\mathrm{CO}_{2}$-TPD) were performed separately to assess the acid and base sites of the catalysts, respectively. A very similar protocol was used for both analyses. Firstly, $150 \mathrm{mg}$ of catalyst was pre-treated by heating up to $500{ }^{\circ} \mathrm{C}$ and kept at this temperature for $1 \mathrm{~h}$ under a flow of $60 \mathrm{~mL} \mathrm{~min}{ }^{-1}$ of He. After that, the samples were cooled to $120{ }^{\circ} \mathrm{C}$ for $\mathrm{NH}_{3}$ adsorption or to $50{ }^{\circ} \mathrm{C}$ for $\mathrm{CO}_{2}$ adsorption. Then, a flow of 30 $\mathrm{mL} \min ^{-1}$ of either $\mathrm{NH}_{3}(1 \%$ in $\mathrm{He}, \mathrm{v} / \mathrm{v})$ during 0.5 h or pure $\mathrm{CO}_{2}$ for $2 \mathrm{~h}$ was fed into the reactor. The physically adsorbed $\mathrm{NH}_{3}$ or $\mathrm{CO}_{2}$ were purged for $1 \mathrm{~h}$ at the same temperature in which the adsorption process occurred. Upon heating from the respective adsorption temperature to $600{ }^{\circ} \mathrm{C}$, with a heating rate of $10^{\circ} \mathrm{C} \mathrm{min^{-1 }}$ and under a flow of $30 \mathrm{~mL} \mathrm{~min}^{-1}$ of $\mathrm{He}, \mathrm{NH}_{3}$ or $\mathrm{CO}_{2}$ desorption was monitored by a thermal conductivity detector of the Micromeritics Pulse Chemisorb 2705 equipment.

Profiles of temperature programmed reduction with hydrogen $\left(\mathrm{H}_{2}\right.$-TPR) of the calcined copper catalysts were performed using a Micromeritics Autochem 2920 equipment. A

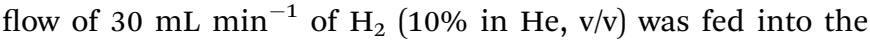


reactor and the temperature was raised from room temperature to $500{ }^{\circ} \mathrm{C}$ using a heating rate of $10{ }^{\circ} \mathrm{C} \mathrm{min}^{-1}$. The hydrogen consumption was monitored using a thermal conductivity detector. Using the same equipment, $\mathrm{N}_{2} \mathrm{O}$ chemisorption experiments were performed to estimate the metallic surface area of the dispersed $\mathrm{Cu}^{0}$ species. The sample was previously reduced at $250{ }^{\circ} \mathrm{C}$ for $30 \mathrm{~min}$, and then cooled to $30{ }^{\circ} \mathrm{C}$ and exposed to a flow of $30 \mathrm{~mL} \mathrm{~min}{ }^{-1}$ of $\mathrm{N}_{2} \mathrm{O}(1 \%$ in $\mathrm{He}, \mathrm{v} / \mathrm{v})$ for $10 \mathrm{~min}$. It is expected that the AlMgO support do not exhibit a significant interaction with $\mathrm{N}_{2} \mathrm{O}$ at this temperature. A second $\mathrm{H}_{2}$-TPR was performed by increasing the temperature up to $400{ }^{\circ} \mathrm{C}$. The hydrogen consumption was used to calculate the amount of surface oxidized copper after $\mathrm{N}_{2} \mathrm{O}$ chemisorption. No bulk oxidation was observed for samples. The copper surface area $\left(S_{\mathrm{Cu}}\right)$ and particle isometric size $\left(d_{\mathrm{Cu}}\right)$ were estimated by using eqn (1) and (2), respectively, and a correlation of $1.46 \times$ $10^{19} \mathrm{Cu}$ atoms per $\mathrm{m}^{2}$ and a stoichiometry of reduction of $2 \mathrm{Cu} /$ $\mathrm{H}_{2}$ were found.

$$
\begin{gathered}
S_{\mathrm{Cu}}=6.4955 \times 10^{-2} \times C \times D \\
d_{\mathrm{Cu}}=6 \frac{\left(V_{\mathrm{m}} / A_{\mathrm{m}}\right)}{D}
\end{gathered}
$$

In eqn (1) and (2), $C$ is the copper content in wt $\%, D$ is the copper dispersion in $\%, V_{\mathrm{m}}$ is the mean atomic density of copper in $\mathrm{g} \mathrm{mL}^{-1}$ and $A_{\mathrm{m}}$ is the atomic surface area in $\mathrm{nm}^{2}$ per atom..$^{30}$

In situ XANES measurements at the Cu K-edge $(8979 \mathrm{eV})$ was carried out at the D06A-DXAS beamline of the Brazilian Synchrotron Light Laboratory (LNLS) at Campinas, Brazil. The D06A-DXAS beamline was equipped with a focusing curved $\mathrm{Si}$ (111) monochromator, operating in the Bragg mode for the selection of the desired range of X-ray wavelengths (8900-9400 $\mathrm{eV}$ ). The samples were prepared as self-supported pellets containing $25 \mathrm{mg}$ of catalyst mixed with boron nitride and placed into a tubular quartz furnace $(d=20 \mathrm{~mm}$ and X-ray path length $=440 \mathrm{~mm}$ ) sealed with Kapton refrigerated windows for the transmission measurements. Temperature-resolved XANES spectra at the $\mathrm{Cu}$ K-edge were acquired during TPR experiments in which it was used a flow of $30 \mathrm{~mL} \mathrm{~min}^{-1}$ of $\mathrm{H}_{2}(5 \%$ in $\mathrm{He}, \mathrm{v} / \mathrm{v})$ and a heating rate of $10^{\circ} \mathrm{C} \mathrm{min}^{-1}$ from room temperature up to $250{ }^{\circ} \mathrm{C}$. The calibration energy and normalization of XANES spectra were performed using the Athena graphical interface program. The information about the proportion of copper species $\left(\mathrm{Cu}^{2+}, \mathrm{Cu}^{+}\right.$and $\left.\mathrm{Cu}^{0}\right)$ during the $\mathrm{H}_{2}$-TPR experiments for $\mathrm{Cu} / \mathrm{AlMgO}$ samples was achieved by the linear combination fitting (LCF) of known $\mathrm{CuO}, \mathrm{Cu}_{2} \mathrm{O}$ and metallic $\mathrm{Cu}$ species.

Diffuse reflectance infrared Fourier transform spectroscopy (DRIFTS) of CO adsorption on copper catalysts were recorded using a Thermo Nicolet iS50 FTIR spectrophotometer equipped with a MCT detector and a Harrick diffuse reflectance infrared Fourier transform spectroscopy cell with a $\mathrm{CaF}_{2}$ window. The spectra were collected on a basis of 40 scans and a resolution of $4 \mathrm{~cm}^{-1}$ using $150 \mathrm{mg}$ of sample. Initially, the samples were pretreated at $500{ }^{\circ} \mathrm{C}$ for $30 \mathrm{~min}\left(10{ }^{\circ} \mathrm{C} \mathrm{min}^{-1}\right)$ under a flow of $\mathrm{He}$ of $100 \mathrm{~mL} \mathrm{~min}{ }^{-1}$, and then, cooled down and reduced at $250^{\circ} \mathrm{C}$ $\left(10^{\circ} \mathrm{C} \mathrm{min}^{-1}\right)$ under a flow of $100 \mathrm{~mL} \mathrm{~min}^{-1}$ of $\mathrm{H}_{2}(5 \%$ in $\mathrm{He}, \mathrm{v} / \mathrm{v})$. The samples were cooled down to $25^{\circ} \mathrm{C}$ under a He flow. The reduced catalysts were exposed to a flow of $100 \mathrm{~mL} \mathrm{~min}^{-1}$ of CO $2 \%$ in $\mathrm{He}, \mathrm{v} / \mathrm{v}$ during $30 \mathrm{~min}$ until saturation, and afterwards purged with a flow of $100 \mathrm{~mL} \mathrm{~min}{ }^{-1}$ of He before the DRIFTS spectra were collected. The temperature was then increased to $500{ }^{\circ} \mathrm{C}$ at a rate of $10{ }^{\circ} \mathrm{C} \mathrm{min}{ }^{-1}$ in $\mathrm{He}\left(100 \mathrm{~mL} \mathrm{~min}^{-1}\right)$. The CO adsorption spectra had two main signals centered at $2099 \mathrm{~cm}^{-1}$ (corresponding to an assemblage of $\mathrm{Cu}^{0}+\mathrm{Cu}^{+}$species) and 2105$2107 \mathrm{~cm}^{-1}$ (corresponding to $\mathrm{Cu}^{+}$species)..$^{21,31}$

\subsection{Catalytic activity}

A microactivity reference system (PID Eng\&Tech), operating in continuous flow mode at atmospheric pressure, was used to perform the dehydrogenative coupling of ethanol. The reactor and main valves were inside a hot box kept heated at $180{ }^{\circ} \mathrm{C}$ to avoid condensation of liquid reactants and products. The catalyst was reduced in situ at $250{ }^{\circ} \mathrm{C}$ under a flow of 30 $\mathrm{mL} \mathrm{min}^{-1}$ of $\mathrm{H}_{2}\left(5 \%\right.$ in $\left.\mathrm{N}_{2}, \mathrm{v} / \mathrm{v}\right)$. A fixed bed reactor was used to perform the reactions at $300{ }^{\circ} \mathrm{C}$ for $6 \mathrm{~h}$ using $150 \mathrm{mg}$ of powdered catalyst. The reactor was fed with ethanol ( $99 \mathrm{wt} \%)$ at a flow rate of $0.1 \mathrm{~mL} \mathrm{~min}^{-1}$, through a HPLC pump (Model 307,

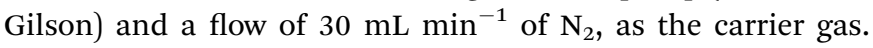
These conditions resulted in a weight hourly space velocity (WHSV, stands for weight hourly space velocity and calculated as feed room temperature mass flow/catalyst mass) of $31.1 \mathrm{~h}^{-1}$. The experiments at lower space velocity of $4.7 \mathrm{~h}^{-1}$ were achieved by using $240 \mathrm{mg}$ of catalyst. The outlet products were analyzed on line using a gas chromatograph (Model 2014, Shimadzu) equipped with a flame ionization detector and a capillary Rtx-1 column of $30 \mathrm{~m} \times 0.32 \mathrm{~mm}$ ID and a film thickness of $1 \mu \mathrm{m}$.

\section{Results and discussion}

\subsection{Textural characteristics of the porous supports and chemical speciation of the dispersed copper sites}

The effect of PSDAs in the textural properties of the supports and, consequently, on those of the copper catalysts was studied by means of mercury intrusion porosimetry, nitrogen physisorption and scanning electron microscopy (Fig. 1 and Table 1). The mixed oxide, AlMgO-P, synthesized in the presence of PSDAs presented considerably higher pore volume and BET area than the reference non-porous support as a consequence of the voids left after removal of the emulsifier agent ( $n$-dodecane). A previous study elucidated that the porosity is created by the stacking of layers of the hydrotalcites precursors randomly positioned around $n$-dodecane droplets. ${ }^{18,19}$ The macropores arose from the droplets of $n$-dodecane, while the mesopores were due to the slit-like arrangement of layers of the precursors. Although the hydrotalcite structure no longer exist after calcination of the samples, the porous characteristic is preserved and it can be useful for the dispersion of active metal sites and for improved accessibility of chemicals. After copper nitrate impregnation and calcination, $\mathrm{Cu} / \mathrm{AlMgO}-\mathrm{P}$ sample showed a great decrease in the pore volume and surface area. It can be related to the partial blockage of pores, as well as to a collapse of 

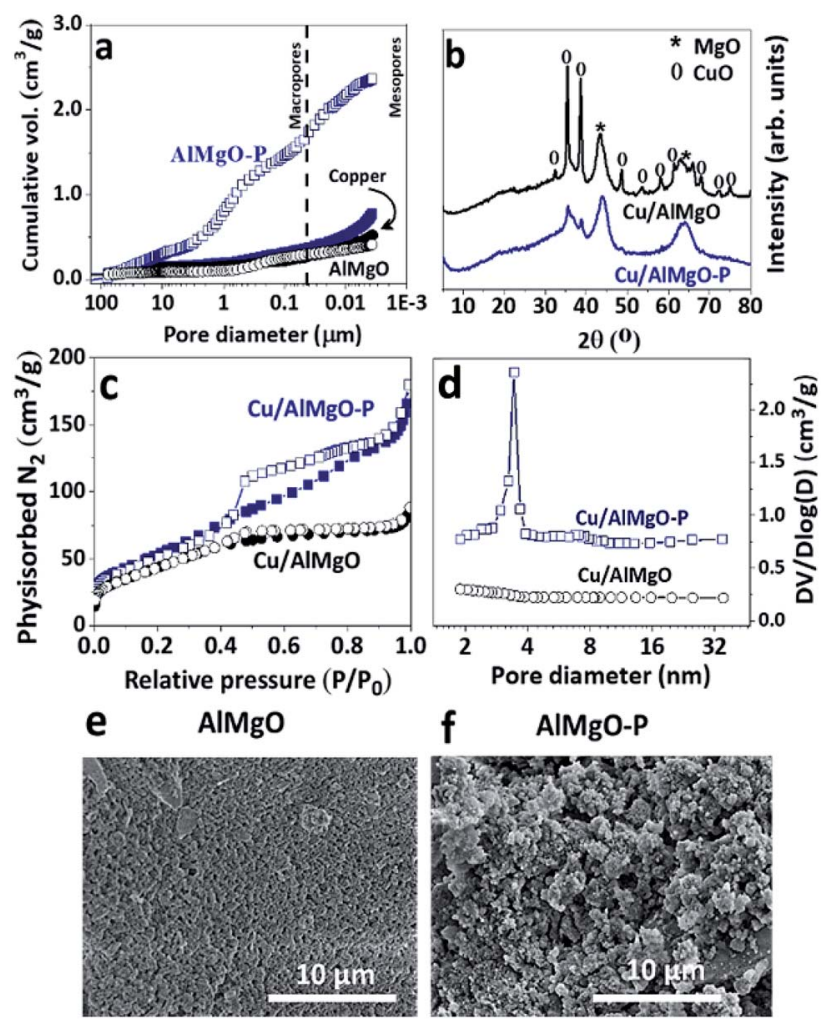

Fig. 1 (a) Mercury intrusion porosimetry (opened and filled symbols represent the supports and the copper containing catalysts, respectively); (b) X-ray diffraction; (c) nitrogen physisorption (opened and filled symbols represent the desorption and adsorption branches, respectively); (d) $\mathrm{BJH}$ pore size distribution of the desorption branches for $\mathrm{Cu} / \mathrm{AlMgO}$ samples; and scanning electron microscopy images of: (e) AlMgO and (f) AlMgO-P supports.

the pore walls during the process of impregnation and drying. Table 1 shows the results of a drying experiment of sample AlMgO-P that was put in contact with water and rotaevaporated in order to follow the impact of sample drying. The pores shrank from 3.7 to $1.7 \mathrm{~cm}^{3} \mathrm{~g}^{-1}$ only due to capillary action of evaporating water. Considering that for the sample containing copper $\mathrm{Cu} / \mathrm{AlMgO}-\mathrm{P}$ the pore volume was much smaller, i.e. 0.8 $\mathrm{cm}^{3} \mathrm{~g}^{-1}$, both pore blockage and capillary forces were possibly responsible for that decrease. The same behavior was observed by Cassinelli et al. that studied porous $\mathrm{Cu} / \mathrm{Al}_{2} \mathrm{O}_{3} \cdot{ }^{6}$
Fig. 1b shows the X-ray diffraction patterns of the copper catalysts. The reference sample exhibited mainly diffraction peaks at $43.4^{\circ}(200), 64.3^{\circ}(220)$ and at $32.5^{\circ}(110), 35.4^{\circ}(002)$, $38.6^{\circ}(111), 48.5^{\circ}(202), 53.6^{\circ}$ (021) corresponding to $\mathrm{MgO}$ and $\mathrm{CuO}$ structures, respectively. On the other hand, the porous support exhibited only diffraction peaks corresponding to $\mathrm{MgO}$, as an indication of higher dispersion of copper oxides. Possibly, due to capillarity effects during drying of impregnated samples, copper solution flows into the pore voids of the porous support, allowing a high dispersion of copper species. According to earlier studies performed with copper supported on $\gamma-\mathrm{Al}_{2} \mathrm{O}_{3},{ }^{32,33}$ the formation of a monolayer coverage and, consequently, saturation of the surface occurs at a loading in-between 4 and $5 \mathrm{wt} \%$ of copper per $100 \mathrm{~m}^{2} \mathrm{~g}^{-1}$ of the support. The specific area of the reference sample $\mathrm{Cu} / \mathrm{AlMgO}$ is just above this limit ( $10 \mathrm{wt} \%$ of copper for $166 \mathrm{~m}^{2} \mathrm{~g}^{-1}$ ) and surface bulk copper oxide particles are prone to be formed after the saturation of the surface by a copper monolayer. Therefore, most probably, the reference sample contains heterogenous distribution of copper species, constituted by well-dispersed monolayered particles and segregated ones.

Further evidence of the improved textural properties of the porous support was provided by nitrogen physisorption measurements (Fig. 1c) and BJH pore size distribution curves (Fig. 1d). The hysteresis between the adsorption and desorption branches for $\mathrm{Cu} / \mathrm{AlMgO}-\mathrm{P}$ catalyst is typical of the existence of mesopores. The smooth slopes of the isotherms, together with the non-parallel behavior of the adsorption and desorption curves, indicated a distinct $\mathrm{H} 3$ hysteresis cycle for pores with a broad distribution resulting from the aggregation of plate-like particles, particularly for the catalyst $\mathrm{Cu} / \mathrm{AlMgO}-\mathrm{P}$ with an average mesopore diameter of $3.3 \mathrm{~nm}$. The preparation method provided a catalyst with a BET area greater than the reference (Table 1).

The metallic copper dispersion was assessed by nitrous oxide chemisorption followed by temperature programed reduction with hydrogen (Fig. 1S $\dagger$ ). Firstly, the catalysts were reduced under a hydrogen stream at $250{ }^{\circ} \mathrm{C}$ for complete reduction of copper, followed by exposure to dilute nitrous oxide flow that caused the oxidation of the surface copper species forming an oxygen layer around the metallic particles. The stoichiometry of the reduction of the surface copper oxides allowed to estimate the relative contribution of surface copper species. Table 2

Table 1 Pore volumes determined by mercury intrusion porosimetry, BET specific surface area and acid and base sites quantification by adsorption of $\mathrm{NH}_{3}$ and $\mathrm{CO}_{2}$, respectively

\begin{tabular}{|c|c|c|c|c|c|c|}
\hline \multirow[b]{2}{*}{ Sample } & \multicolumn{3}{|c|}{ Pore volume $\left(\mathrm{cm}^{3} \mathrm{~g}^{-1}\right)$} & \multirow[b]{2}{*}{ BET area $\left(\mathrm{m}^{2} \mathrm{~g}^{-1}\right)$} & \multirow{2}{*}{$\frac{\text { Acid sites }}{\text { Total } \mathrm{NH}_{3}\left(\mathrm{mmol} \mathrm{g}^{-1}\right)}$} & \multirow{2}{*}{$\begin{array}{l}\text { Base sites } \\
\text { Total } \mathrm{CO}_{2}\left(\mathrm{mmol} \mathrm{g}^{-1}\right)\end{array}$} \\
\hline & Meso & Macro & Total & & & \\
\hline AlMgO-P & 1.8 & 1.9 & 3.7 & 260 & 0.43 & 0.43 \\
\hline $\mathrm{Cu} / \mathrm{AlMgO}$ & 0.2 & 0.3 & 0.5 & 120 & 0.29 & 0.40 \\
\hline $\mathrm{Cu} / \mathrm{AlMgO}-\mathrm{P}$ & 0.4 & 0.4 & 0.8 & 206 & 0.36 & 0.37 \\
\hline
\end{tabular}

${ }^{a}$ AlMgO-P sample put in water and evaporated, simulating copper wet impregnation. 
Table 2 Copper dispersion, metallic area and particle size for copper impregnated on AIMgO supports, before (B) and after (A) ethanol dehydrogenation reaction carried out at $300^{\circ} \mathrm{C}$ and WHSV of $31.1 \mathrm{~h}^{-1}$

\begin{tabular}{lllll}
\hline & Sample & $\begin{array}{l}\text { Cu dispersion } \\
(\%)\end{array}$ & $\begin{array}{l}\text { Metallic area } \\
\left(\mathrm{m}^{2} \mathrm{~g}^{-1}\right)\end{array}$ & $\begin{array}{l}\text { Particle size } \\
(\mathrm{nm})\end{array}$ \\
\hline \multirow{2}{*}{$\mathrm{B} \quad$} & Cu/AlMgO & 50 & 29 & 2.1 \\
& Cu/AlMgO-P & 85 & 55 & 1.2 \\
A & Cu/AlMgO & 42 & 27 & 2.5 \\
& Cu/AlMgO-P & 50 & 34 & 2.1
\end{tabular}

illustrates the dispersion degrees, $\mathrm{Cu}$ surface area and $\mathrm{Cu}$ average particle size. As expected, the $\mathrm{Cu} / \mathrm{AlMgO}-\mathrm{P}$ catalyst had a superior dispersion of copper of $85 \%$ in comparison to the $50 \%$ of the reference sample, thus confirming the positive effect of the emulsion mediated synthesis in producing a porous support for dispersing copper. The dispersion degree and the average $\mathrm{Cu}$ particle size follow the same pattern as $\mathrm{Cu}$ surface area, i.e. for $\mathrm{Cu} / \mathrm{AlMgO}-\mathrm{P}$ high dispersion leads to a low particle size $(1.2 \mathrm{~nm})$. It is worthy to note that compared with appropriate literature data obtained over copper-based mesoporous materials, $\mathrm{Cu} / \mathrm{AlMgO}-\mathrm{P}$ catalyst shows very high dispersion and surface area for copper. For example, at similar copper loading of $10 \mathrm{wt} \%$, copper supported on all-silica mesoporous SBA-15 material had only $37 \%$ of copper dispersion. ${ }^{34}$

Additional information about copper species distribution on supports was provided by XANES spectra (Fig. $2 \mathrm{~S} \dagger$ ) during reduction of copper by heating from 25 to $400{ }^{\circ} \mathrm{C}$ under a $\mathrm{H}_{2} / \mathrm{He}$ atmosphere. For the reference catalyst, the $\mathrm{CuO}$ reduction started at approximately $25 \mathrm{~min}$ after heating (plateau of $220^{\circ} \mathrm{C}$ in Fig. 2) promoting only a minor change in the spectra of Fig. $2 \mathrm{~S}, \dagger$ related to the direct transformation of $\mathrm{Cu}^{2+}$ to $\mathrm{Cu}^{0}$, without the clear identification of a shoulder in the ascending margin around $9002 \mathrm{eV},{ }^{5,6,21,27}$ a fingerprint of the presence of

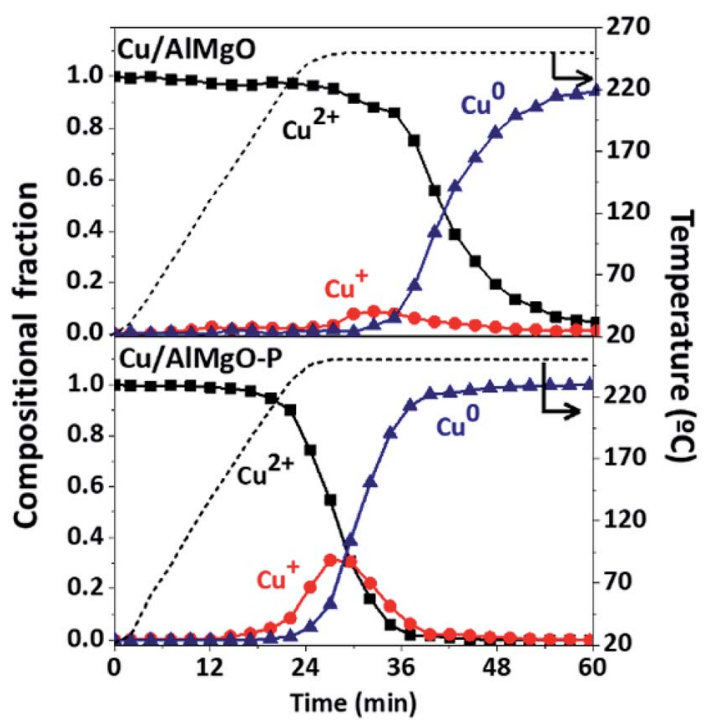

Fig. 2 Copper species along reduction with $\mathrm{H}_{2}$ up to $250{ }^{\circ} \mathrm{C}$ for the $\mathrm{Cu} / \mathrm{AlMgO}$ and Cu/AlMgO-P catalysts, obtained from XANES measurements at $\mathrm{Cu} \mathrm{K}$-edge (spectra are in Fig. $2 \mathrm{~S}^{\dagger}$ ).
$\mathrm{Cu}^{+}$intermediate during the reduction process. On the other hand, the porous samples submitted to the reduction treatment exhibited a noticeable shoulder in the ascending margin of the spectrum. The LCF of the XANES spectra in Fig. 2 shows that in fact the copper on the catalyst $\mathrm{Cu} / \mathrm{AlMgO}$ reduces from $\mathrm{Cu}^{2+}$ to $\mathrm{Cu}^{0}$ with a minor formation of the $\mathrm{Cu}^{+}$intermediate. For the $\mathrm{Cu} /$ AlMgO-P catalyst, although the reduction of $\mathrm{Cu}^{2+}$ to $\mathrm{Cu}^{+}$started earlier, at approximately 20 min under $\mathrm{H}_{2}$ stream, $\mathrm{Cu}^{+}$reached a portion close to $25 \%$ that can be associated to a kinetically controlled reduction of $\mathrm{Cu}^{+}$to $\mathrm{Cu}^{0}$, possibly due to the monolayer dispersion of copper species on the AlMgO-P support. Since, $\mathrm{Cu}^{+}$was previously considered the most active species to promote the activation of ethanol, ${ }^{5,6}$ its formation is highly desirable for the ethanol dehydrogenation reactions.

FTIR spectra of $\mathrm{CO}$ adsorbed on reduced copper catalysts in the high frequency (HF) region of $2160-2020 \mathrm{~cm}^{-1}$ and in the low frequency (LF) region of $1850-1150 \mathrm{~cm}^{-1}$ are shown in Fig. 3 and $3 \mathrm{~S}, \uparrow$ respectively. It has been reported ${ }^{35}$ that $\mathrm{CO}$ adsorption on copper surfaces show IR bands in the HF spectral region associated with linear or bridged CO species interacting with
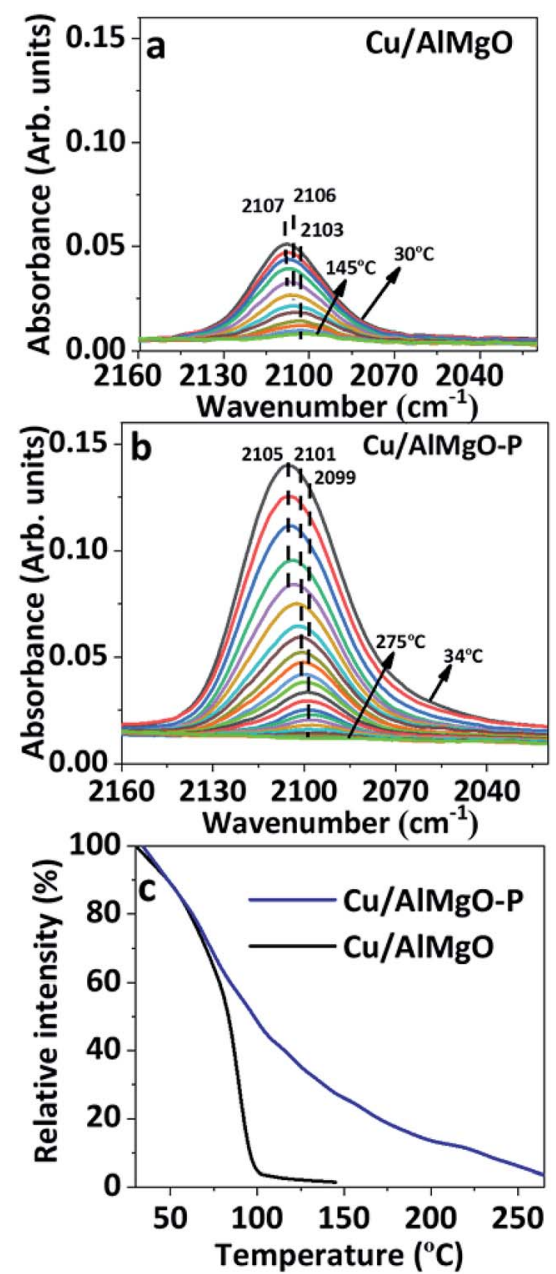

Fig. 3 FTIR spectra of $\mathrm{CO}$ desorption on reduced: (a) $\mathrm{Cu} / \mathrm{AlMgO}$; (b) $\mathrm{Cu} / \mathrm{AlMgO}-\mathrm{P}$ catalysts in the region of $2160-2020 \mathrm{~cm}^{-1}$; (c) relative intensity of bands displayed in (a) and (b) vs. desorption temperature of $\mathrm{CO}$. 
copper species, such as, $\mathrm{Cu}_{2} \mathrm{O}$ or $\mathrm{Cu}^{0}$ sites. However, herein, based on the XANES results of copper supported samples, $\mathrm{CuO}$ specie is highly improbable, and the three strong overlapping bands with maximum at 2107, 2106 and $2103 \mathrm{~cm}^{-1}$ of $\mathrm{Cu} /$ AlMgO-P catalyst are probably related to chemisorption of $\mathrm{CO}$ over $\mathrm{Cu}^{+}$and/or $\mathrm{Cu}^{0}$ species (Fig. 3S $\dagger$ ). According to Hadjiivanov et al.,$^{36}$ linear $\mathrm{Cu}^{0}-\mathrm{CO}$ carbonyls may be adsorbed at the same frequency, as $\mathrm{Cu}^{+}-\mathrm{CO}$, when copper is highly dispersed on the surface. These copper species are better distinguished via thermal stability, once the $\mathrm{Cu}^{0}$-CO surface carbonyls are easily wrecked by increasing temperature, whereas the $\mathrm{Cu}^{+}$cations produce more stable surface carbonyls, as a result of the strongest $\sigma$-bond. ${ }^{31,35}$ Fig. $3 \mathrm{c}$ shows the relative intensity of chemisorbed CO bands in the spectra of Fig. 3a and b, normalized by their maximum intensity. Carbonyl species adsorbed on $\mathrm{Cu} / \mathrm{AlMgO}$ catalyst are totally absent at $150{ }^{\circ} \mathrm{C}$, while for the $\mathrm{Cu} / \mathrm{AlMgO}-\mathrm{P}$ catalyst complete desorption of $\mathrm{CO}$ occurred at $255^{\circ} \mathrm{C}$, that may be related to the higher amount of surface $\mathrm{Cu}^{+}$. The LF region in Fig. $4 \mathrm{~S} \dagger$ presented bands at 1635, $1547,1375,1343$ and $1220 \mathrm{~cm}^{-1}$, referring to carbonate species interacting with basic surface sites as $\mathrm{OH}$ groups and $\mathrm{O}^{2-}$ centers or even acid-base pairs (due $\mathrm{Mg}^{2+}-\mathrm{O}^{2-}-\mathrm{Al}^{3+}$ ), which are very similar for both samples, as expected by the TPD- $\mathrm{CO}_{2}$, which showed minor differences for samples $\mathrm{Cu} / \mathrm{AlMgO}$ and $\mathrm{Cu} / \mathrm{AlMgO}-\mathrm{P}$ (Table 1 and Fig. 5S $\dagger$ ). The bands located at 1635 and $1220 \mathrm{~cm}^{-1}$ are attributed to bridged bidentate carbonates (b- $\mathrm{HCO}_{3}{ }^{-}$), whereas the bands 1547 and $1375 \mathrm{~cm}^{-1}$ and $1343 \mathrm{~cm}^{-1}$ are assigned to carbonate monodentate $\left(\mathrm{m}-\mathrm{CO}_{3}{ }^{2-}\right)$ and bidentate $\left(\mathrm{b}-\mathrm{CO}_{3}{ }^{2-}\right)$, respectively. ${ }^{13}$ Typically, monodentate carbonate formation requires low-coordination oxygen anions (strong base sites), provided by $\mathrm{MgO}^{13}$

The acid and base properties of the copper catalysts were determined from the temperature programmed desorption (TPD) of $\mathrm{NH}_{3}$ or $\mathrm{CO}_{2}$, respectively. Fig. 5S $\dagger$ shows the TPD profiles of $\mathrm{NH}_{3}$ and $\mathrm{CO}_{2}$ and the integration of the peaks are given in Table 1 . The deconvolution by means of a Gaussian function was used to discriminate the desorption peaks for weak, medium and strong sites (Fig. 5S $\dagger$ ), which reflect the different binding acid-base sites available on the surface. The porous support (AlMgO-P) presented lower acidity than the reference $(\mathrm{AlMgO})$, as reported in the previous study. ${ }^{19}$ The explanation was based on the reduction of hydroxyl groups in the surface of the AlMgO-P sample due to the interaction with the hydrophobic emulsion during the synthesis that leads to a support with a considerably low acidity and basicity. In comparison to other supports found in the literature (see data collection in Table 1S $\dagger$ ), hydrotalcites derived oxides are among those with lower acidity/basicity. By supporting copper, the catalyst had a pronounced decrease in acidity due to the selective combination of the Lewis alkaline sites from copper oxides with acidic sites on AlMgO-P. A milder decrease in basicity was also observed, which may be related to binding of $\mathrm{Cu}$ to certain base sites as well. However, these events were fairly beneficial to avoid the formation of undesired by products, specially ethene and diethyl ether that can be formed on those sites.

\subsection{Dehydrogenative reactions of ethanol to acetaldehyde and ethyl acetate}

The copper impregnated catalysts were investigated in the dehydrogenation of ethanol (Scheme 1) at $300{ }^{\circ} \mathrm{C}$ under space velocities of $31.1 \mathrm{~h}^{-1}$ (Fig. 4) and $4.7 \mathrm{~h}^{-1}$ (Fig. 5), and under a period of $6 \mathrm{~h}$ to evaluate the activity and deactivation. Catalytic tests were also performed using the Cu-free supports (Fig. 6S $\dagger$ ) and the ethanol conversion was negligible, being below 1\%. On the other hand, the copper catalysts, had a high activity in selectively converting ethanol into acetaldehyde (Fig. 4), reaching conversion values of 28 and $61 \%$ for $\mathrm{Cu} / \mathrm{AlMgO}$ and $\mathrm{Cu} / \mathrm{AlMgO}-\mathrm{P}$ samples, respectively. Ethyl acetate, ethene, diethyl ether, $n$-butanal, crotonaldehyde, methyl ethyl ketone, acetone and butanol were minor products summing less than $2 \%$. Thus, the porous catalyst was about 3 times more active, because of the higher dispersion of copper and creation of a singular environment that led to the formation of $\mathrm{Cu}^{+}$species on the catalyst surface. In fact, the presence of partially reduced copper $\mathrm{Cu}^{+}$and $\mathrm{Cu}^{0}$ are advantageous for the catalytic performance, as the initial turnover frequencies, considering the surface copper, were 122 and $166 \mathrm{~h}^{-1}$ for the reference and for the porous catalyst, respectively.

The catalysts were not completely steady for a time-onstream (TOS) of $6 \mathrm{~h}$. The notable deactivation of the $\mathrm{Cu}$ / AlMgO reference sample was related to the harsh copper

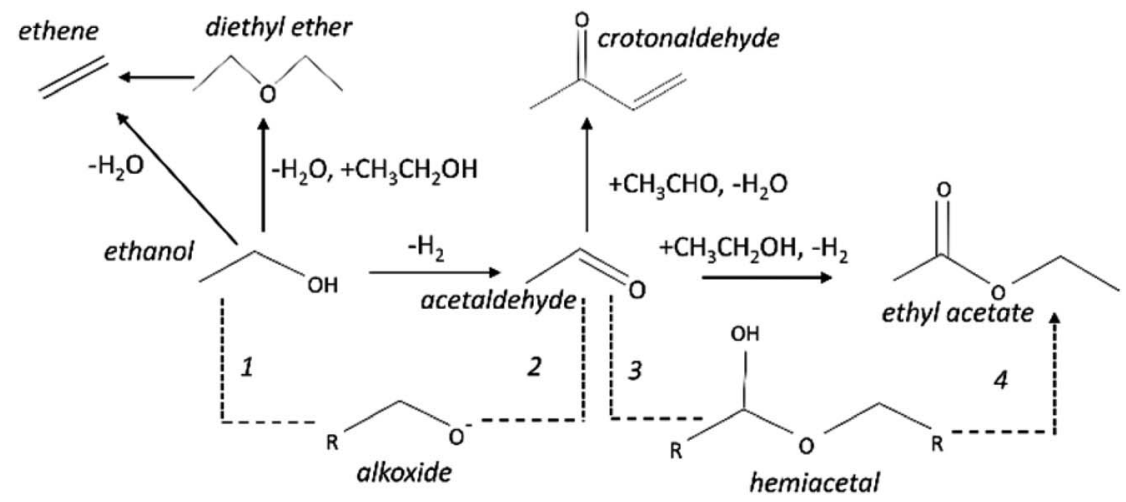

Scheme 1 Dehydrogenative reactions of ethanol to give acetaldehyde and ethyl acetate as main products. The dashed path corresponds to the Tishchenko mechanism that might take place on the support/copper interface. 

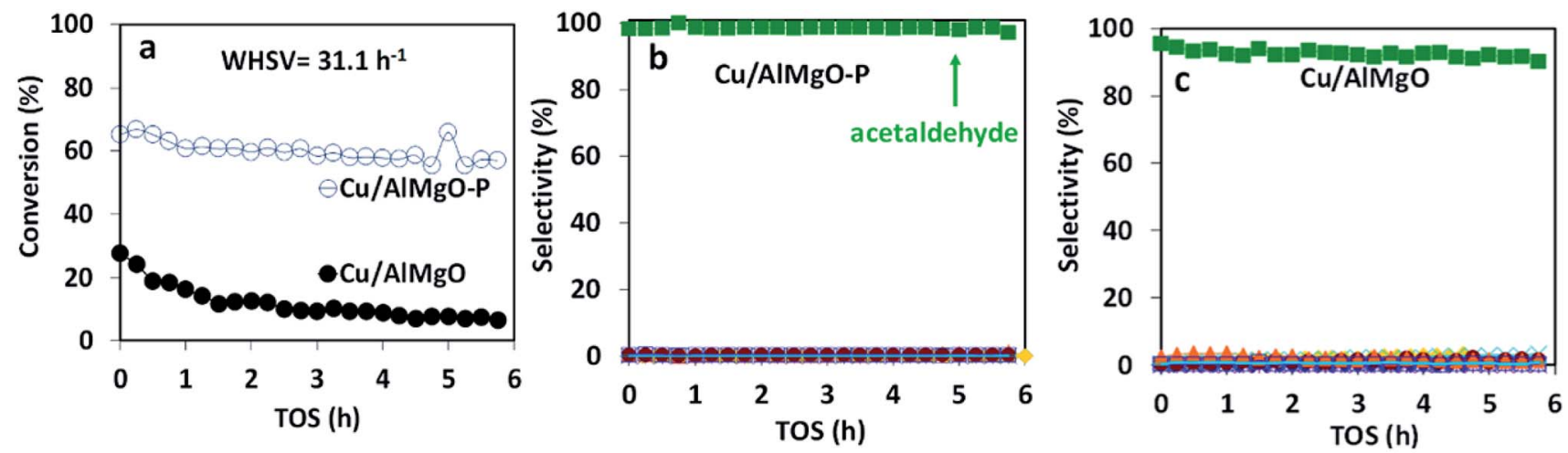

Fig. 4 (a) Conversion of ethanol at $300^{\circ} \mathrm{C}$ and WHSV of $31.1 \mathrm{~h}^{-1}$; (b) selectivity over Cu/AIMgO-P; (c) Cu/AlMgO catalysts. Ethyl acetate, ethene, diethyl ether, butanal, crotonaldehyde, methyl ethyl ketone, acetone and butanol were less than $2 \%$.

dispersion and to the sintering of copper particles that were loosely supported on the non-porous sample. The porous catalyst, in contrast, deactivated less, because of the physical barrier that well dispersed copper particles placed on the surface of macro and mesopores of the support had to sinter. Both catalysts suffered some extent of deactivation along $6 \mathrm{~h}$ at $300{ }^{\circ} \mathrm{C}(21.1 \%$ for $\mathrm{Cu} / \mathrm{AlMgO}$ against $8.2 \%$ for $\mathrm{Cu} / \mathrm{AlMgO}-\mathrm{P})$ as a consequence of a slow copper sintering, as revealed by chemisorption experiments depicted in Table 2, however, its effect was more pronounced on the non-porous reference catalyst.

Ethanol conversion was also examined at a WHSV of $4.7 \mathrm{~h}^{-1}$ (Fig. 5), i.e. by decreasing the space velocity and consequently increasing the contact time in 6.6 times. Ethanol conversion and selectivity to all products were noticeably improved: the conversion increased by a factor of 3.5 and 1.4 , for the reference and for the porous catalyst, respectively. The main product, ethyl acetate, was mostly produced on the reference non-porous catalyst (35 against $20 \%$ on the porous one). That behavior reveals that the coupling reaction of ethanol and acetaldehyde is favored on larger copper particles. ${ }^{37}$ The differences in selectivity to ethyl acetate could rely on the support/copper interface, which differs on copper particles of different sizes
(Table $2 \mathrm{~S} \dagger$ ). The result can be explained based on the Tishchenko mechanism, ${ }^{7,37-40}$ which consists of four main steps depicted in Scheme 1 and that involve the participation of the support/copper interface. Firstly, it occurs the formation an alkoxide $\left(\mathrm{CH}_{3} \mathrm{CH}_{2} \mathrm{O}^{-}\right)$adsorbed on AlMgO base sites (step 1) that reacts with the aldehyde formed on the copper phase (step 2). At this step, the presence of $\mathrm{Cu}^{+}$in combination with $\mathrm{Cu}^{0}$ aids to promote the formation of acetaldehyde (which is more evident in the porous catalyst). Then, the alkoxide reacts with the aldehyde to form a hemiacetal (step 3). Finally, the hemiacetal dehydrogenates on copper phase (step 4). According to the results of Scotti et al. that studied $\mathrm{Cu} / \mathrm{ZrO}_{2}$ catalysts ${ }^{40}$ we can predict herein that the steps 1 and 4 are promoted by $\mathrm{AlMgO} / \mathrm{Cu}$ interface and that improved hydrogen spillover takes place, thus allowing the interface to work fittingly. It seems that the interface plays a major role in the overall catalyst performance, because the superior capacity of the porous catalyst to dehydrogenate ethanol did not allow to obtain higher selectivity to ethyl acetate. Lastly, the cooperative effect of acid and base sites of suitable strength of the $\mathrm{Al}-\mathrm{Mg}$ oxides was important to give high selectivity to ethyl acetate, as reported elsewhere., ${ }^{7,40}$

In order to confirm that the catalyst deactivation was due to copper sintering and not to coke deposition, after running
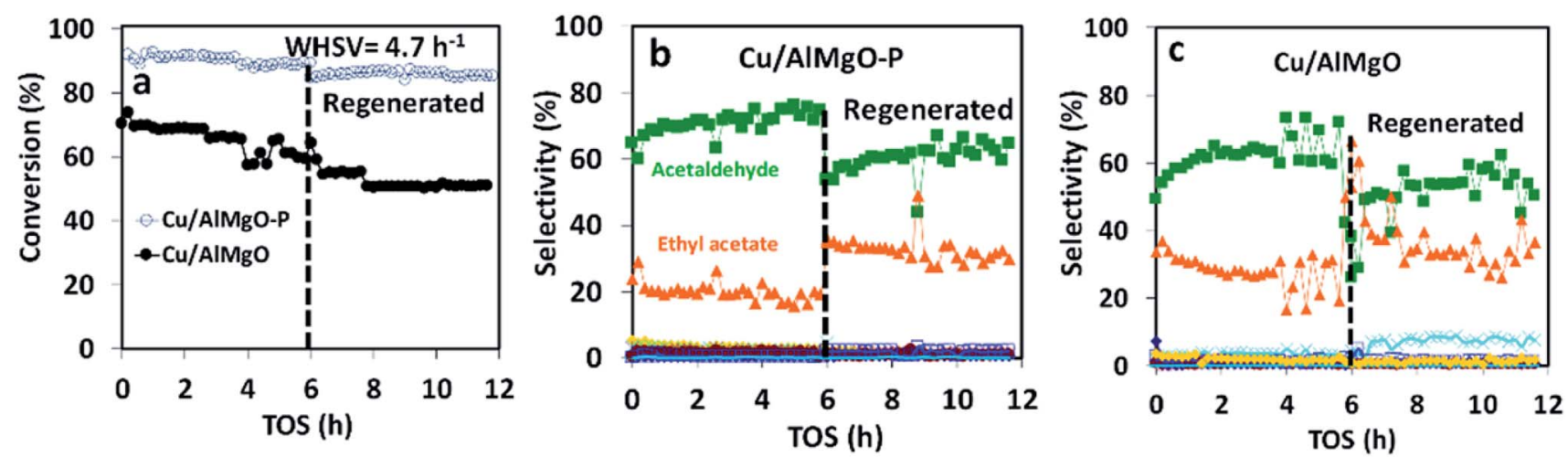

Fig. 5 (a) Conversion of ethanol at $300{ }^{\circ} \mathrm{C}$ and WHSV of $4.7 \mathrm{~h}^{-1}$; (b) selectivity over Cu/AlMgO-P; (c) Cu/AlMgO catalysts, before and after regeneration by calcination at $500^{\circ} \mathrm{C}$ and reduction at $250^{\circ} \mathrm{C}$. Diethyl ether, butanal, crotonaldehyde, methyl ethyl ketone, acetone and butanol were less than $2 \%$. 
ethanol dehydrogenation for $6 \mathrm{~h}$ the catalysts were calcined at $500{ }^{\circ} \mathrm{C}$ followed by reduction at $250{ }^{\circ} \mathrm{C}$ in $\mathrm{H}_{2}$. After regeneration, the catalytic activity was not restored at all and the copper particle size increased (Fig. 5 and Table 2). The increase in particle size between 2-2.5 $\mathrm{nm}$ appears to favor to increase the selectivity of ethyl acetate to about $40 \%$ and decrease acetaldehyde to about $55 \%$. Also, the regeneration process leads to an increase of sintering of the copper particles of the catalysts which increased ethyl acetate selectivity up to about $8 \%$. The sintering process is more evident in the non-porous $\mathrm{Cu} / \mathrm{AlMgO}$ (Fig. 5c). Finally, after the thermal treatment at $500{ }^{\circ} \mathrm{C}$ and sintering of copper, the surface of the support led to the occurrence of the dehydration on ethanol to ethene, with a selectivity of about $5 \%$.

\section{Conclusions}

Hydrotalcite derived mixed oxides of $\mathrm{Al}$ and $\mathrm{Mg}$ were successfully prepared by an emulsion mediated method and impregnated with copper nitrate. The combination of texture characterization techniques, such as mercury porosimetry and nitrogen physisorption, disclosed the production of a more porous material with a higher BET area. The acidity and basicity of the catalysts decreased after impregnation with copper, due to metal coating on these sites. The porous catalyst exhibited more available metallic sites and greater dispersion on the surface of the material, as demonstrated by $\mathrm{H}_{2}$-TPR together with $\mathrm{N}_{2} \mathrm{O}$ chemisorption.

From the LCF of XANES spectra and FTIR-CO measurements, the presence of a larger amount of $\mathrm{Cu}^{+}$intermediate was observed, which was advantageous for the conversion of ethanol to acetaldehyde, as the turnover frequencies, were 122 and $166 \mathrm{~h}^{-1}$ for the non-porous reference and for the porous catalyst, respectively. Both catalysts deactivated due to copper sintering, however the porous catalyst deactivated less, because of the difficulties that the physical barrier related with a higher surface area generated by the presence of macro and mesopores, which allowed to well disperse the copper particles and consequently minimizing their sintering. By increasing the contact time by 6.6 times, the formation of ethyl acetate was mostly favored on the non-porous catalyst, because its formation is favored on the support/copper interface given by larger copper particles.

\section{Conflicts of interest}

There are no conflicts to declare.

\section{Acknowledgements}

The authors gratefully acknowledge the financial support provided by the São Paulo State Research Foundation (FAPESP, grant numbers \#2013/01328-0 and \#2015/05321-5) and CNPq (grant number \#306326/2017-5). The authors also acknowledge the XAFS1 beamline of the Brazilian Synchrotron Light Laboratory (LNLS) for the XAS measurements, LCE-UFSCar for SEM images and Prof. J. M. C. Bueno for the CO/DRIFTS adsorption experiments.

\section{References}

1 E. S. Shuba and D. Kifle, Renewable Sustainable Energy Rev., 2018, 81, 743-755.

2 H. H. Mardhiah, H. C. Ong, H. H. Masjuki, S. Lim and H. V. Lee, Renewable Sustainable Energy Rev., 2017, 67, 1225-1236.

3 A. G. Sato, D. P. Volanti, D. M. Meira, S. Damyanova, E. Longo and J. M. C. Bueno, J. Catal., 2013, 307, 1-17.

4 A. G. Sato, D. P. Volanti, I. C. De Freitas, E. Longo, J. Maria and C. Bueno, Catal. Commun., 2012, 26, 122-126.

5 W. H. Cassinelli, L. Martins, M. Magnani, S. H. Pulcinelli, V. Briois and C. V. Santilli, RSC Adv., 2016, 6, 20453-20457.

6 W. H. Cassinelli, L. Martins, A. R. Passos, S. H. Pulcinelli, A. Rochet, V. Briois and C. V. Santilli, ChemCatChem, 2015, 7, 1668-1677.

7 F. Zaccheria, N. Scotti and N. Ravasio, ChemCatChem, 2018, 10, 1-11.

8 D. A. Morgenstern and J. P. Fornango, Energy Fuels, 2005, 19, 1708-1716.

9 S. K. Rout, S. Guin, K. K. Ghara, A. Banerjee and B. K. Patel, Org. Lett., 2012, 14, 3982-3985.

10 J. Zhang, G. Leitus, Y. Ben-David and D. Milstein, J. Am. Chem. Soc., 2005, 127, 10840-10841.

11 H. Miura, K. Nakahara, T. Kitajima and T. Shishido, ACS Omega, 2017, 2, 6167-6173.

12 S. W. Colley, J. Tabatabaei, K. C. Waugh and M. A. Wood, J. Catal., 2005, 236, 21-33.

13 V. K. Diez, C. R. Apesteguia and J. I. Di Cosimo, J. Catal., 2003, 215, 220-233.

14 P. J. Luggren, C. R. Apesteguía and J. I. Di Cosimo, Fuel, 2016, 177, 28-38.

15 P. J. Luggren, C. R. Apesteguía and J. I. Di Cosimo, Top. Catal., 2016, 59, 196-206.

16 J. J. Bravo-Suárez, B. Subramaniam and R. V. Chaudhari, Appl. Catal., A, 2013, 455, 234-246.

17 J. T. Kozlowski and R. J. Davis, ACS Catal., 2013, 3, 15881600.

18 D. D. Petrolini, E. A. Urquieta-González, S. H. Pulcinelli, C. V. Santilli and Martins, Microporous Mesoporous Mater., 2017, 240, 149-158.

19 D. D. Petrolini, A. V. da Silva Neto, E. A. Urquieta-González, S. H. Pulcinelli, C. V. Santilli and L. Martins, RSC Adv., 2018, 8, 6039-6046.

20 D. D. Petrolini, S. H. Pulcinelli, C. V. Santilli and L. Martins, J. Sol-Gel Sci. Technol., 2014, 71, 9-15.

21 P. C. P. Caldas, J. M. R. Gallo, A. Lopez-Castillo, D. Zanchet and J. M. C. Bueno, ACS Catal., 2017, 7, 1-28.

22 R. A. Hoyt, M. M. Montemore, E. C. H. Sykes and E. Kaxiras, J. Phys. Chem. C, 2018, 122, 21952-21962.

23 J. Quesada, L. Faba, E. Díaz and S. Ordonez, ChemCatChem, 2018, 10, 3583-3592.

24 M. Ohira, H. Liu, D. He, Y. Hirata, M. Sano, T. Suzuki and T. Miyake, J. Jpn. Pet. Inst., 2018, 61, 205-212. 
25 Z. Lu, D. Gao, H. Yin, A. Wang and S. Liu, Ind. Eng. Chem. Res., 2015, 31, 301-308.

26 E. V. Shelepova, L. Y. Ilina and A. A. Vedyagin, React. Kinet., Mech. Catal., 2017, 122, 385-398.

27 I. Ro, Y. Liu, M. R. Ball, D. H. K. Jackson, J. P. Chada, C. Sener, T. F. Kuech, R. J. Madon, G. W. Huber and J. A. Dumesic, ACS Catal., 2016, 6, 7040-7050.

28 E. W. Washburn, Proc. Natl. Acad. Sci. U. S. A., 1921, 7, 115116.

29 S. J. Gregg, K. S. W. Sing and H. W. Salzberg, J. Electrochem. Soc., 1967, 114, 279C.

30 H. Masuda, M. Suzuki, K. Ehara, M. Fuji, T. Fukui, H. Suzuki, J. Tatami, K. Hayashi and K. Toda, Nanoparticle Technology Handbook, 2008, pp. 3-48.

31 W. W. Wang, W. Z. Yu, P. P. Du, H. Xu, Z. Jin, R. Si, C. Ma, S. Shi, C. J. Jia and C. H. Yan, ACS Catal., 2017, 7, 1313-1329.
32 B. R. Strohmeier, D. E. Leyden, R. S. Field and D. M. Hercules, J. Catal., 1985, 94, 514-530.

33 R. Friedman, J. Catal., 1978, 55, 10-28.

34 C. S. Chen, C. C. Chen, C. T. Chen and H. M. Kao, Chem. Commun., 2011, 47, 2288-2290.

35 M. Neurock, Z. Tao, A. Chemburkar, D. D. Hibbitts and E. Iglesia, Faraday Discuss., 2017, 197, 59-86.

36 K. I. Hadjiivanov and G. N. Vayssilov, Adv. Catal., 2002, 47, 307-511.

37 J. Sun and Y. Wang, ACS Catal., 2014, 4, 1078-1090.

38 M. Nielsen, H. Junge, A. Kammer and M. Beller, Angew. Chem., Int. Ed., 2012, 51, 5711-5713.

39 P. C. Zonetti, J. Celnik, S. Letichevsky, A. B. Gaspar and L. G. Appel, J. Mol. Catal. A: Chem., 2011, 334, 29-34.

40 N. Scotti, F. Zaccheria, C. Evangelisti, R. Psaro and N. Ravasio, Catal. Sci. Technol., 2017, 7, 1386-1393. 